\title{
Effects of interactive teaching on university students' knowledge and attitude toward reproductive health: a pilot study in Jordan
}

This article was published in the following Dove Press journal: Journal of Multidisciplinary Healthcare

\begin{abstract}
Reem A Ali'
Ahlam Alnatour ${ }^{2}$

Karimeh Alnuaimi'

Fatmeh Alzoubi'

Maysa Almomani ${ }^{3}$

Areej Othman ${ }^{4}$

'Department of Maternal and Child Health Nursing, Faculty of Nursing, Jordan University of Science and Technology, Irbid, Jordan; ' 2Department of Community and Mental Health Nursing, Faculty of Nursing, Jordan University of Science and Technology, Irbid, Jordan; ${ }^{3}$ Department of Adult Health Nursing, Faculty of Nursing, Jordan University of Science and Technology, Irbid, Jordan; ${ }^{4}$ Department of Maternal and Child Health Nursing, School of Nursing, The University of Jordan, Amman, Jordan
\end{abstract}

Background: Youths in Jordan lack knowledge related to reproductive health $(\mathrm{RH})$. Interactive teaching methods showed positive results in enhancing health awareness and adopting healthy practices among students.

Objectives: The objective of this study was to examine the usefulness of interactive teaching in promoting health awareness of RH among nonmedical university students in Jordan.

Methods: We employed a quasi-experimental one group pretest and posttest design for a purposive sample of 210 students (18-24 years). Knowledge and attitudes regarding RH issues were assessed using a questionnaire developed by the researchers.

Results: A significant improvement in students' knowledge and attitudes toward RH was evident. Female students had higher scores on knowledge than male students in the pretest; this difference was smaller in the posttest. Also, female students had significantly more positive attitudes toward RH in pretest than males, although this difference vanished in the posttest. Study results indicated that students benefit from study intervention regardless their gender.

Conclusion: Integrating RH into university's curriculum coupled with interactive learning approach is a powerful way to promote $\mathrm{RH}$ awareness among youths.

Keywords: STIs, young adult, family planning, premarital examination, health promotion

\section{Introduction}

Youth aged $15-24$ years constitute $\sim 21.5 \%$ of the population of Jordan. ${ }^{1}$ During these years, sexual maturation and the ability to reproduce occur, although most of the Jordanian youth go through this period with only vague information on reproductive health (RH), ${ }^{2}$ including early marriage, safe sex, family planning, and sexually transmitted infections (STIs). ${ }^{3-6}$ Even among university students, only medical and health sciences students may be exposed to the knowledge about RH as a part of their university education. Education curricula in Arab countries rarely focus on RH, and if it exists, it is mostly skipped by teachers who are unprepared to handle these issues with school-aged children. ${ }^{7}$ Given that university students as young adults are expected to marry and establish families, knowledge regarding $\mathrm{RH}$ is crucial not only to prevent possible health problems but also to promote their health.

Several studies highlighted the lack of understanding of RH among Jordanians. ${ }^{2,8-10}$ Khalaf et $\mathrm{al}^{2}$ reported that limited use of RH services among adolescents (12-18 years) in Jordan was in part due to inadequate knowledge about RH. Attitudes and practices regarding $\mathrm{RH}$ that were reported by Jordanian women and men raised a concern, for
Department of Maternal and Child Health Nursing, Faculty of Nursing, Jordan University of Science and Technology, PO Box 3030, 221 10 Irbid, Jordan

Tel +962 27201000 Ext 23717

Email raali@just.edu.jo 
example, women are generally held responsible for $\mathrm{RH}$, whereas men have final decision on number of children. ${ }^{3,8}$ Also, almost one third of the surveyed women $(n=4,076)$ do not believe that modern contraceptive methods are more effective than traditional methods, reported the desire to have more children to make larger families, and said that having a male child remains a social norm. ${ }^{8}$

In addition, the early marriage rate in Jordan raised another concern. With reference to reports by UNICEF, ${ }^{11}$ there is no significant decline in the rates of child marriages registered in Jordanian courts from 2005 to 2013 . These reports coupled with the maternal mortality rate in Jordan -58 deaths $/ 100,000$ live births raise a serious concern about people's RH in Jordan. ${ }^{12}$ Increasing the awareness among youths about RH may contribute to improving the health of mothers, children and reducing population growth.

One of the methods to promote health is through education. It has been evident in the literature that health education at the university environment is a cost-effective and ideal method of developing healthy lifestyles related, for example, to nutrition and physical activities among university students. ${ }^{13,14}$ Educational programs including topics about early marriage, family planning, STIs, and reproductive rights are needed. Haberland ${ }^{15}$ in his review found that sex education programs were effective in bringing favorable outcomes among adolescents such as increased knowledge and decreased STIs. However, there is a lack of studies that describe using the interactive teaching method to educate youths about RH in conservative societies such as Jordan.

The purpose of this study was to examine the usefulness of an interactive teaching approach in promoting health awareness of RH in Bachelor of Science nonmedical students in Jordan. Given that knowledge about RH has a great impact on people's morbidity, mortality, and life expectancy worldwide, conducting research studies is crucial in this area, particularly for young adults. The knowledge that would be generated from this study has the potential to enhance curriculum development and teaching approaches used at the university level in order to help young adults to maintain and promote their RH as a part of their general health. This is in the hope of bridging the accessibility of knowledge gap between the genders regarding $\mathrm{RH}$ in Jordan.

\section{Methods}

This pilot study was a part of "Youth and Future Health" project. This project examined methods to promote a healthy lifestyle among university students. For the current pilot study, an intervention quasi-experimental design was employed to evaluate the usefulness of introducing $\mathrm{RH}$ topics by using interactive teaching methods for university students. The study design involves one group pretest and posttest, to assess changes in Bachelor of Science students' knowledge and attitudes toward $\mathrm{RH}$. A purposive sample of students (18-24 years) at Jordan University of Science and Technology (JUST) was used. JUST is the biggest university in the country that enrolls students from all over the country. All students who were enrolled in health promotion course during summer semester 2016 were eligible to be in the study.

The study instrument was developed based on relevant studies to meet the purpose of measuring knowledge and attitudes toward $\mathrm{RH}$ aspects taking into consideration culture and social norms in Jordan. RH aspects of our study were rights and gender equality, marriage and premarital physical examination, family planning, and STIs. Researchers who developed the instrument obtained a special training from United Nations Population Fund (UNFPA) in preparing health promotion course material that covers RH. The study questionnaire included demographic sheet and knowledge and attitude toward RH. The knowledge scale consisted of 14 items tapping on selected issues related to RH. Response items were rated on a 3-point response format (yes, no, and do not know). Responses were scored as 1 for correct response or 0 for incorrect and "I do not know" responses. The attitude scale consisted of 21 items tapping on the same RH issues. The scale items are rated as "disagree" $(0)$ or "not sure" (1) or "agree" (2) responses. The total score ranges from 0 to 42 with higher scores indicating more positive attitude.

Both knowledge and attitude scales were reviewed for content and face validity by a panel of experts. The knowledge scale items were analyzed individually, whereas for the attitude scale, a total score was obtained by summing the items scores. Internal consistency for the attitude scale was assessed and found to be satisfactory. Cronbach's alpha $=0.65$, which is acceptable for a newly developed scale.

\section{Intervention}

Health promotion course is an elective course offered by the school of nursing. For the first time, knowledge about RH was integrated into the health promotion course. Interactive teaching classes on RH were given to students for 4 weeks as a 60-minute class per day for 5 days a week. All professors who delivered the course had a special training in employing interactive teaching methods to promote $\mathrm{RH}$ in youth. The interactive teaching methods included brainstorming, debate, open-end questions, group discussion, individual and group activities, educational games, and reflections on real-life stories and videos/articles that were related to RH topics. Details about study intervention are summarized in Table 1. 
Table I Detailed study intervention

\begin{tabular}{|c|c|c|c|c|c|}
\hline \multirow[t]{2}{*}{ Week/topic } & Day I & Day 2 & Day 3 & Day 4 & Day 5 \\
\hline & Brainstorming & $\begin{array}{l}\text { Dig deeper by } \\
\text { asking compelling } \\
\text { questions } \\
\text { (discussion) }\end{array}$ & $\begin{array}{l}\text { Class debate or hands-on } \\
\text { group activity* }\end{array}$ & $\begin{array}{l}\text { Reflection on } \\
\text { articles/movies } \\
\text { or news/real-life } \\
\text { story }\end{array}$ & Learn by teaching* \\
\hline Orientation week & \multicolumn{5}{|c|}{$\begin{array}{l}\text { Orientation about the interactive teaching method, introduction to stu } \\
\text { Pretest survey that was available for } 3 \text { days before starting the classes }\end{array}$} \\
\hline $\begin{array}{l}\text { Week 2: Marriage } \\
\text { and STIs } \\
\text { Week 3: Pregnancy } \\
\text { and family planning }\end{array}$ & $\begin{array}{l}\text { The professor used } \\
\text { the whiteboard } \\
\text { to list all possible } \\
\text { ideas spontaneously } \\
\text { provided by students } \\
\text { about the selected } \\
\text { topic of the week. } \\
\text { Then grouping words } \\
\text { that were provided } \\
\text { by students under a } \\
\text { few headings. This } \\
\text { is done to reach } \\
\text { to the definition }\end{array}$ & $\begin{array}{l}\text { The professor } \\
\text { provided students } \\
\text { with four questions } \\
\text { tapping on the selected } \\
\text { topic of the week. } \\
\text { The teacher asked a } \\
\text { question and then gave } \\
\text { time for students to } \\
\text { think and respond. For } \\
\text { sensitive questions, } \\
\text { written response } \\
\text { was gathered. The } \\
\text { professor gathered }\end{array}$ & $\begin{array}{l}\text { The class is divided into six } \\
\text { groups; each group consists } \\
\text { of } 5-8 \text { students. Three groups } \\
\text { argued for another three } \\
\text { groups against the resolution. } \\
\text { The time is divided equally } \\
\text { between the affirmative (I5 } \\
\text { minutes) and negative groups } \\
\text { ( } 15 \text { minutes) and then both } \\
\text { sides of the debate were given } \\
\text { time for rebuttal and summary } \\
\text { for their case ( } 5 \text { minutes for } \\
\text { each). }\end{array}$ & $\begin{array}{l}\text { Out-of-class } \\
\text { assignment: the } \\
\text { professor provided } \\
\text { students with } \\
\text { articles/video/ } \\
\text { story. The students } \\
\text { were asked to read } \\
\text { an article/story } \\
\text { or watch a movie } \\
\text { that is related to } \\
\text { the selected topic } \\
\text { of the week and } \\
\text { develop a written }\end{array}$ & $\begin{array}{l}\text { Students are divided } \\
\text { into four groups and } \\
\text { were given a topic to } \\
\text { read and synthesize } \\
\text { material to teach their } \\
\text { classmates. } \\
\text { Students selected } \\
\text { the topics that were } \\
\text { related to reproductive } \\
\text { health. Students were } \\
\text { encouraged to use an } \\
\text { interactive method of } \\
\text { teaching in presenting }\end{array}$ \\
\hline $\begin{array}{l}\text { Week 4: Gender } \\
\text { and equity }\end{array}$ & $\begin{array}{l}\text { and element of } \\
\text { the selected topic. } \\
\text { All students (50) } \\
\text { in the class were } \\
\text { encouraged to } \\
\text { participate in the } \\
\text { activity. For example, } \\
\text { students were asked: } \\
\text { what does marriage } \\
\text { mean to you? } \\
\text { What does family } \\
\text { planning mean to } \\
\text { you? }\end{array}$ & $\begin{array}{l}\text { a few answers from } \\
\text { students and then } \\
\text { made clarifications, } \\
\text { addressed } \\
\text { misunderstanding and } \\
\text { any questions raised } \\
\text { by students before } \\
\text { leaping to answers } \\
\text { for questions. Each } \\
\text { question took around } \\
\text { I0 minutes. Other } \\
\text { questions had the same } \\
\text { technique. } \\
\text { Examples of the } \\
\text { questions asked to } \\
\text { students are: what } \\
\text { are the premarital } \\
\text { physical examinations } \\
\text { and tests? What is the } \\
\text { appropriate age for } \\
\text { having babies? } \\
\text { These questions } \\
\text { enhanced fruitful } \\
\text { discussion about the } \\
\text { topic. }\end{array}$ & 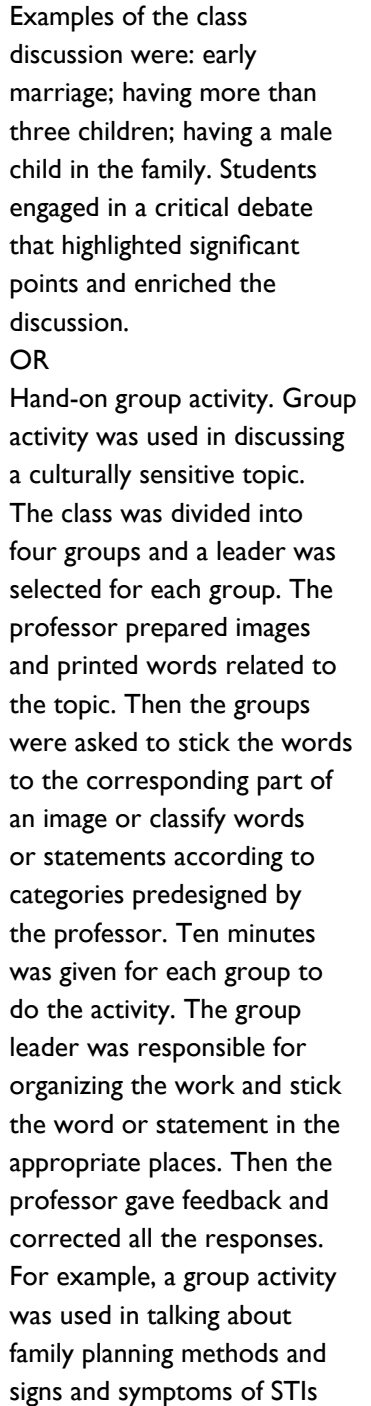 & $\begin{array}{l}\text { reflection. Eight to } \\
\text { I0 students were } \\
\text { allowed to read their } \\
\text { reflection in the class } \\
\text { for } 3 \text { minutes. This } \\
\text { activity can enhance } \\
\text { the student's self- } \\
\text { learning. } \\
\text { Examples of articles: } \\
\text { statistics of divorce } \\
\text { worldwide and } \\
\text { in Jordan; article } \\
\text { about STls among } \\
\text { youth; video about } \\
\text { pregnancy. } \\
\text { OR } \\
\text { Listening to the } \\
\text { students' real } \\
\text { narratives and } \\
\text { experience and then } \\
\text { asking the students } \\
\text { to reflect on it. }\end{array}$ & $\begin{array}{l}\text { their topic. Each group } \\
\text { was given } 20 \text { minutes } \\
\text { to present, } 10 \text { minutes } \\
\text { for questions from } \\
\text { classmates, and } 10 \\
\text { minutes for feedback } \\
\text { from the professor. } \\
\text { The professor } \\
\text { supervised the } \\
\text { students from selecting } \\
\text { the topic to presenting } \\
\text { it in class. }\end{array}$ \\
\hline
\end{tabular}

Note: *Methods involve senses and mobility.

Abbreviation: STIs, sexually transmitted infections. 


\section{Procedure}

Students were notified by email about the study before the course begins. An introductory letter explaining the study purpose, methods, and participants' right was emailed to all students who registered in the health promotion course. Participation in the study was voluntary. During the orientation day, students who desired to participate in the study signed informed consent. The pretest was available on the e-learning for prospective participants. Likewise, at the end of the course, a posttest was available on the e-learning. All data were collected via university portal, and the final files were stored in a password-locked computer with the primary investigator. The study was approved by the institutional review boards at JUST.

The data were analyzed by using the SPSS for Windows version 23 (IBM Corporation, Armonk, NY, USA). McNemar's tests were performed to examine the effect of interactive teaching sessions on students' knowledge scores, and chi-square tests were used to examine gender difference in knowledge scores. Due to violation of the normality assumption in attitude scores as revealed by KolmogorovSmirnov $(p=0.000)$ and Shapiro-Wilk $(p=0.004)$ tests, Wilcoxon analysis was used to examine the effect of the study intervention on students' attitude scores, and MannWhitney $U$ tests were used to examine gender differences on attitude scores on pretest and posttest scores. Assumptions for the selected statistical analyses were checked and adhered to scientific norms. Analyses were conducted with a level of significance set at 0.05 .

\section{Results}

All students $(\mathrm{N}=515)$ who were enrolled in health promotion classes were invited to participate in the study. Of the invited students, 292 agreed and consented to be in the study, making a response rate of $56.7 \%$. Eighty-two of the students did not complete the posttest surveys, even after a couple of reminders by email. The final sample size consisted of 210 students who completed both pretest and posttest surveys. Thus, the actual response rate dropped to $40.78 \%$ in this study. Demographics and descriptive analyses of study variables are summarized in Table 2.

\section{Knowledge of $\mathrm{RH}$}

Detailed information about pretest and posttest scores are presented in Table 3. For the total sample, five items on knowledge obtained high percentage scores on pretest that ranged from $71.9 \%$ to $88.1 \%$. These items increased significantly on posttest. Also, knowledge items with low
Table 2 Demographics of the study participants

\begin{tabular}{ll}
\hline Characteristics/variables & Values \\
\hline Female students & 71.9 \\
Marital status (single) & 98.6 \\
Family size & \\
$3-5$ & 16.3 \\
$6-7$ & 49 \\
$8-10$ & 28.6 \\
$>$ II & 6.3 \\
Unemployed students & 93.3 \\
Free of chronic illness & 95.2 \\
Region & \\
Northern & 76.7 \\
Middle & 22.4 \\
Southern & 1 \\
Family income (Jordanian Dinar) & \\
$\leq 500$ & 25.8 \\
$50 I-800$ & 38.8 \\
$80 I-I, I 00$ & 17.7 \\
I,I0I-I,500 & 5.1 \\
I,50I-I,800 & 1.7 \\
I,80I-2,000 & 4.5 \\
$>2,000$ & 7 \\
Age range I8-28 years (mean [SD]) & 20.05 (SD=I.36) \\
Attitude & \\
Pretest total sample (median) & 30 \\
Male & 28 \\
Female & 30 \\
Posttest total sample (median) & 32 \\
Male & 32 \\
Female & 33 \\
\hline
\end{tabular}

Note: Data presented as percentage, unless otherwise stated.

scores on the pretest significantly increased on posttest. For example, on pretest, the percentage of correct answers on knowledge about risks of repeated pregnancy was $65.2 \%$, and on posttest, the correct response percentage raised to $96.7 \%$. Also, knowledge about signs and symptoms of STIs raised from $42.9 \%$ on pretest to $93.8 \%$ on posttest. Although students' knowledge about birth control pills has improved after the study intervention, $\sim 50 \%$ of students did not know that pills are among the most effective means of family planning.

As shown in Table 4, on pretest, the percentages of correct responses on 12 out of 14 items were higher for female students; of these items, significant differences were found on four items as revealed by chi-square analyses. Likewise, on posttest, females scored higher than males, though the differences between genders were not statistically significant except for one item; the item was related to premarital examinations. Female students' knowledge significantly improved comparing to their counterpart male students, $\chi^{2}$ $(1, \mathrm{n}=210)=4.46, p=0.03$. 
Table 3 McNemar's test analyses of pretest and posttest knowledge correct scores (total sample, $\mathrm{N}=210$ )

\begin{tabular}{|c|c|c|c|c|c|}
\hline No & Knowledge item & Pretest \% & Posttest \% & $\chi^{2}$ & $p$-value \\
\hline \multicolumn{6}{|c|}{ Items obtained high percentage scores in both pretest and posttest } \\
\hline I & Premarriage tests for genetic diseases in Jordan included thalassemia (hereditary anemia) & 88.1 & 96.2 & 9.48 & 0.002 \\
\hline 2 & Some sexually transmitted infections are not cured with antibiotics & 79.5 & 92.4 & 13.80 & 0.000 \\
\hline 3 & $\begin{array}{l}\text { If one or both of the fiancé discovered that they carry the thalassemia gene, she or he is } \\
\text { referred to a medical center for consultation in Jordan }\end{array}$ & 78.1 & 95.2 & 25.52 & 0.000 \\
\hline 4 & Woman's age affects the type of family planning method & 74.8 & 85.2 & 7.35 & 0.007 \\
\hline 5 & $\begin{array}{l}\text { Reproductive health concerns about girls and women's health during childbearing age and } \\
\text { beyond (postmenstruation) }\end{array}$ & 71.9 & 89.5 & 20.57 & 0.000 \\
\hline \multicolumn{6}{|c|}{ Items obtained low percentage scores in pretest and high scores in posttest } \\
\hline 6 & $\begin{array}{l}\text { Burning and itching in the genital area are among the symptoms of sexually transmitted } \\
\text { diseases }\end{array}$ & 42.9 & 93.8 & 96.03 & 0.000 \\
\hline 7 & Women with repeated pregnancies are more susceptible to the risks of pregnancy & 65.2 & 96.7 & 58.68 & 0.000 \\
\hline 8 & A person may contract sexually transmitted disease from one sexual intercourse & 66.7 & 92.9 & 41.07 & 0.000 \\
\hline 9 & $\begin{array}{l}\text { Some new mothers suffer from postpartum depression during the first 3-6 months after } \\
\text { delivery }\end{array}$ & 61 & 90 & 48 & 0.000 \\
\hline 10 & $\begin{array}{l}\text { Reproductive health confirmed the right of an individual to freely choose a spouse, establish } \\
\text { a family, and determine the number of children }\end{array}$ & 61.4 & 88.1 & 35.17 & 0.000 \\
\hline 11 & Reproductive health focuses on both women's and men's role in reproductive health issues & 54.3 & 84.8 & 45.10 & 0.000 \\
\hline 12 & $\begin{array}{l}\text { Sexually transmitted infections may harm the newborn health such as causing congenital } \\
\text { malformations }\end{array}$ & 65.7 & 83.3 & 18.25 & 0.000 \\
\hline 13 & $\begin{array}{l}\text { Premarriage physical examination and tests in Jordan are limited to detect genetic diseases } \\
\text { and does not include sexually transmitted infection tests }\end{array}$ & 38.6 & 73.8 & 45.16 & 0.000 \\
\hline \multicolumn{6}{|c|}{ Item obtained low percentage scores in both pretest and posttest } \\
\hline 14 & Birth control pills are among the most effective means of family planning & 26.2 & 51.4 & 29.08 & 0.000 \\
\hline
\end{tabular}

While examining the usefulness of the study intervention for the total sample using McNemar's analyses, it revealed a significant difference between pretest and posttest knowledge scores across all 14 items. These findings support an improvement in students' knowledge regarding RH.

\section{Attitudes toward $\mathrm{RH}$}

As described in Table 5, almost all the scores on the attitude scale moved toward more positive attitude after the intervention. However, even after the intervention, some results still raise a concern. For example, $28.1 \%$ of students still agree that the presence of a male child in the family is essential, more than a quarter $(30 \%)$ agreed that marriage is not a choice, $54.3 \%$ lay more responsibility on women behalf in terms of using family planning methods, around half (46.2\%) do believe that having children during the first year of marriage strengthen the marital relationship, and more than half $(65.7 \%)$ agreed that if one or both fiancés are carrier to thalassemia genes, they should not marry.

As shown in Table 6, gender differences were obvious on a few items. For example, prior to study intervention, the number of male students who agreed on statements including that "early marriage for girls," "early marriage helps to have more children," "involving extended family members in the family planning issues," and increased number of children will not decrease the chances of welfare of the family" was more than the female students. These differences were statistically significant based on chi-square results. On posttest, the differences between genders were statistically diminished except for two items in which male students agreed more on the "importance of having a male child in a family" and the "importance of having a child during the first year of marriage to stabilize the family." Although these differences were significant based on chi-square results, the difference was marginal. While comparing the total attitude scores between both genders, Mann-Whitney $U$ test revealed a significant difference on pretest scores, in which female students showed more positive attitudes (median $=30$, $\mathrm{n}=210)$ and male (median=28, $\mathrm{n}=210), \mathrm{U}=3412.0, \mathrm{z}=2.64$, $p=0.008, \mathrm{r}=0.18$. For posttest scores, Mann-Whitney $U$ test revealed no significant difference between female students (median=33, $\mathrm{n}=210$ ) and male students (median=32, $\mathrm{n}=210$ ), $\mathrm{U}=4085.0, \mathrm{z}=0.94, p=0.349, \mathrm{r}=0.06$. When examining the usefulness of the study intervention, Wilcoxon-signed rank test showed a statistically significant increment in attitude scores following the interactive teaching, $\mathrm{z}=7.13, p=0.000$, with medium effect size $(\mathrm{r}=0.35)$. The median score on the attitude toward RH increased from pretest (median=30) to posttest scores (median $=32$ ). 
Table 4 Gender differences in pretest and posttest knowledge scores based on chi-square tests

\begin{tabular}{|c|c|c|c|c|c|c|c|c|c|}
\hline \multirow[t]{2}{*}{ No } & \multirow[t]{2}{*}{ Knowledge item } & \multicolumn{4}{|c|}{ Pretest $\%$ of correct answers } & \multicolumn{4}{|c|}{ Posttest $\%$ of correct answers } \\
\hline & & $\begin{array}{l}\text { Male } \\
\mathbf{N}=59\end{array}$ & $\begin{array}{l}\text { Female } \\
N=\mid 5 \text { I }\end{array}$ & $\chi^{2}$ & $p$-value & $\begin{array}{l}\text { Male } \\
\mathbf{N}=59\end{array}$ & $\begin{array}{l}\text { Female } \\
N=|5|\end{array}$ & $\chi^{2}$ & $p$-value \\
\hline \multicolumn{10}{|c|}{$\begin{array}{l}\text { Female students scored significantly higher than male } \\
\text { students in pretest but not in posttest }\end{array}$} \\
\hline I & $\begin{array}{l}\text { Premarriage tests for genetic diseases in Jordan included } \\
\text { thalassemia (hereditary anemia) }\end{array}$ & 76.3 & 92.7 & 9.43 & 0.002 & 96.6 & 96 & 0.00 & 1 \\
\hline 2 & $\begin{array}{l}\text { Some new mothers suffer from postpartum depression } \\
\text { during the first 3-6 months after delivery }\end{array}$ & 44.1 & 67.5 & 8.87 & 0.003 & 89.8 & 90.1 & 0.00 & 0.96 \\
\hline 3 & $\begin{array}{l}\text { Reproductive health confirmed the right of an individual to } \\
\text { freely choose a spouse, establish a family, and determine the } \\
\text { number of children }\end{array}$ & 47.5 & 66.9 & 5.96 & 0.02 & 84.7 & 89.4 & 0.49 & 0.48 \\
\hline \multicolumn{10}{|c|}{$\begin{array}{l}\text { Female students scored significantly higher than male } \\
\text { students in both tests }\end{array}$} \\
\hline 4 & $\begin{array}{l}\text { Premarriage physical examination and tests in Jordan are } \\
\text { limited to detect genetic diseases and does not include } \\
\text { sexually transmitted infection tests }\end{array}$ & 27.1 & 43 & 3.9 & 0.04 & 62.7 & 78.1 & 4.46 & 0.03 \\
\hline \multicolumn{10}{|c|}{$\begin{array}{l}\text { Female students scored higher than male students in both } \\
\text { tests }\end{array}$} \\
\hline 5 & $\begin{array}{l}\text { Reproductive health concerns about girls and } \\
\text { women's health during childbearing age and beyond } \\
\text { (postmenstruation) }\end{array}$ & 62.7 & 75.5 & 2.83 & 0.09 & 88.1 & 90.1 & 0.03 & 0.87 \\
\hline 6 & $\begin{array}{l}\text { Reproductive health focuses on both women's and men's } \\
\text { role in reproductive health issues }\end{array}$ & 49.2 & 56.3 & 0.61 & 0.44 & 81.4 & 86.1 & 0.42 & 0.52 \\
\hline 7 & $\begin{array}{l}\text { Women with repeated pregnancies are more susceptible to } \\
\text { the risks of pregnancy }\end{array}$ & 64.4 & 65.6 & 0.000 & I & 96.6 & 96.7 & 0.00 & 1 \\
\hline 8 & $\begin{array}{l}\text { Birth control pills are among the most effective means of } \\
\text { family planning }\end{array}$ & 22 & 27.8 & 0.47 & 0.495 & 45.8 & 53.6 & 0.76 & 0.38 \\
\hline 9 & $\begin{array}{l}\text { If one or both of the fiancé discovered that they carry the } \\
\text { thalassemia gene, she or he is referred to a medical center } \\
\text { for consultation in Jordan }\end{array}$ & 72.9 & 80.1 & 0.91 & 0.34 & 94.9 & 95.4 & 0.00 & 1 \\
\hline 10 & $\begin{array}{l}\text { Burning and itching in the genital area are among the } \\
\text { symptoms of sexually transmitted diseases }\end{array}$ & 39 & 44.4 & 0.31 & 0.58 & 93.2 & 94 & 0.00 & 1 \\
\hline II & $\begin{array}{l}\text { Sexually transmitted infections may harm the newborn } \\
\text { health such as causing congenital malformations }\end{array}$ & 62.7 & 66.9 & 0.169 & 0.68 & 81.4 & 84.1 & 0.07 & 0.78 \\
\hline \multicolumn{10}{|c|}{$\begin{array}{l}\text { Male students scored higher than female students in } \\
\text { pretest }\end{array}$} \\
\hline 12 & $\begin{array}{l}\text { Some sexually transmitted infections are not cured with } \\
\text { antibiotics }\end{array}$ & 84.7 & 77.5 & 0.96 & 0.33 & 91.5 & 92.7 & 0.00 & 0.99 \\
\hline 13 & $\begin{array}{l}\text { A person may contract sexually transmitted disease from } \\
\text { one sexual intercourse }\end{array}$ & 78 & 62.3 & 4.03 & 0.04 & 91.5 & 93.4 & 0.03 & 0.86 \\
\hline \multicolumn{10}{|c|}{$\begin{array}{l}\text { Male students scored higher than female students in } \\
\text { posttest }\end{array}$} \\
\hline 14 & Woman's age affects the type of family planning method & 74.6 & 74.8 & 0.000 & I & 89.8 & 83.4 & 0.92 & 0.34 \\
\hline
\end{tabular}

Note: Bold represents $p<0.05$, which is a significant result.

\section{Discussion}

RH is an essential aspect of the population's general health, yet youths in Jordan are lacking pertinent knowledge. Evidence from this study indicated significant knowledge deficit in critical aspects of RH such as family planning and signs and symptoms of STIs among youths which is consistent with the previous findings. ${ }^{2,3,5}$ We identified many misconceptions and negative attitudes that need attention. Students' knowledge and positive attitudes toward RH were highlighted as well.
Prior to the current study, intervention students had some knowledge about the most common hereditary diseases in Jordan (thalassemia) and its premarital tests and seriousness of STIs. Students might have gained this level of knowledge from national awareness campaigns via mass media and social media platforms. Gender differences were obvious; female students had higher scores on almost all items on pretest results. These differences were significant in some aspects of students' knowledge, including hereditary diseases in Jordan, postpartum depression, and what constitutes RH. 
Table 5 Percentage of agree responses on baseline and post attitude scores

\begin{tabular}{|c|c|c|c|}
\hline \multirow[t]{2}{*}{ No } & \multirow[t]{2}{*}{ Item } & \multirow{2}{*}{$\begin{array}{l}\text { Pretest ( } n, \% \text { agree) } \\
N=210\end{array}$} & \multirow{2}{*}{$\begin{array}{l}\text { Posttest (n, \% agree) } \\
\mathrm{N}=210\end{array}$} \\
\hline & & & \\
\hline I & $\begin{array}{l}\text { Having more than four children in the family may decrease the chances welfare of family } \\
\text { members }\end{array}$ & $142(67.6)$ & $160(76.2)$ \\
\hline 2 & $\begin{array}{l}\text { If a couple decided to have a certain number of children, it is worth not to do birth } \\
\text { spacing* }\end{array}$ & $32(15.2)$ & $36(17.1)$ \\
\hline 3 & The presence of a male child in the family is something essential* & $90(42.9)$ & $59(28.1)$ \\
\hline 4 & $\begin{array}{l}\text { It is necessary to introduce reproductive health to a school curriculum that fits school } \\
\text { children ages }\end{array}$ & $193(91.9)$ & $195(92.9)$ \\
\hline 5 & $\begin{array}{l}\text { The benefits of family planning not only are reflected on individuals and families but also } \\
\text { extend to communities }\end{array}$ & $200(95.2)$ & $199(94.8)$ \\
\hline 6 & $\begin{array}{l}\text { The participation of the extended family members (eg, mother-in-law and siblings) in family } \\
\text { planning decisions is important in the consolidation of extended family and social relations* }\end{array}$ & $41(19.5)$ & $41(19.5)$ \\
\hline 7 & $\begin{array}{l}\text { The decision about birth spacing and selecting family planning method is a shared decision } \\
\text { between the couple }\end{array}$ & $203(96.7)$ & $204(97.1)$ \\
\hline 8 & Women need the social support of her partner in matters related to family planning & $203(96.7)$ & $206(98.1)$ \\
\hline 9 & A man has to accompany his wife for consultation related to family planning & $201(95.7)$ & $202(96.2)$ \\
\hline 10 & $\begin{array}{l}\text { Family planning methods should be tried by women first, and if it does not work, methods } \\
\text { for men could be used. * }\end{array}$ & $134(63.8)$ & II4 (54.3) \\
\hline 11 & Marriage is predestined and fated and is not a choice* & $86(4 I)$ & $63(30)$ \\
\hline 12 & I am in favor of early marriage to the girl before the age of I8 years* & $10(4.8)$ & $3(1.4)$ \\
\hline 13 & Early marriage helps to have more children* & $64(30.5)$ & $54(25.7)$ \\
\hline 14 & $\begin{array}{l}\text { Having a child during the first year of marriage strengthens the marital relationship and } \\
\text { supports its stability* }\end{array}$ & $107(5 \mathrm{I})$ & $97(46.2)$ \\
\hline 15 & The main purpose of marriage is procreation and reproduction only* & $14(6.7)$ & $6(2.9)$ \\
\hline 16 & $\begin{array}{l}\text { Early marriage (before } 18 \text { years of age) is one of the important factors that lead to } \\
\text { instability of marriage, thus the occurrence of divorce }\end{array}$ & $157(74.8)$ & $164(78.1)$ \\
\hline 17 & $\begin{array}{l}\text { Discussing intimacy issues by young women and men with their parents is unacceptable } \\
\text { before marriage* }\end{array}$ & $57(27.1)$ & $46(21.9)$ \\
\hline 18 & $\begin{array}{l}\text { If one or both of the fiancés discovered that they carry the gene for thalassemia, they } \\
\text { should not marry* }\end{array}$ & $144(68.6)$ & $138(65.7)$ \\
\hline 19 & Contracting sexually transmitted infections is divine punishment that affects bad people* & $57(27.1)$ & $55(26.2)$ \\
\hline 20 & $\begin{array}{l}\text { It is better not to raise the subject of premarital physical examination related to sexually } \\
\text { transmitted diseases* }\end{array}$ & $21(10)$ & $13(6.2)$ \\
\hline 21 & $\begin{array}{l}\text { If someone discovered that he has a sexually transmitted disease, the patient should forever } \\
\text { be separated from her/his partner* }\end{array}$ & $124(59)$ & $96(45.7)$ \\
\hline
\end{tabular}

Note: *Reversed items for the total score.

These results are consistent with a previous survey. ${ }^{16}$ These positive findings may reflect the cultural norms in Jordan. Jordanian women generally hold more responsibilities regarding procreation, thus they seek more information regarding $\mathrm{RH}$ issues. This gender difference regarding $\mathrm{RH}$ knowledge should be taken into consideration when providing health education to youth, in order to meet their needs.

Positive findings related to attitudes toward $\mathrm{RH}$ were identified prior to the study intervention, in which almost all students agreed upon the extent of the benefits of family planning and that men and women have equal rights with regard to family planning decisions. The majority of the students did not favor early marriage and agreed that it has negative implications on the stability of the family. In addition, most of them disagree that the purpose of marriage is only for procreation. These promising findings may be due in part to the educational level of study participants or/and as a result of the awareness campaigns regarding $\mathrm{RH}$. However, the self-report questionnaire that was used in this study may invite socially desirable responses. Nevertheless, these positive aspects can be further strengthened and solidified by health education.

Gender difference was pronounced on a few items prior to the study intervention. Although all students did not favor "early marriage, 'involving extended family members in family planning issues,' 'large family size,' and early marriage to have more children," female students showed more opposition than male students. These findings mainly related to the shifting of gender roles in our society. Nowadays women are more educated, engaged in paid labor and striving for 
Table 6 Gender differences in pretest and posttest attitude scores based on chi-square tests

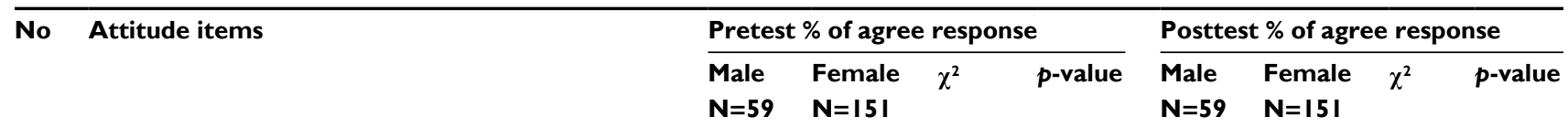

\section{Female students had significantly more positive} attitudes than male students in pretest

I Having more than four children in the family may decrease the chances welfare of family members

2 The participation of the extended family members (eg,

$\begin{array}{llllllll}55.9 & 72.2 & \mathbf{9 . 0 5} & \mathbf{0 . 0 1} & 67.8 & 79.5 & 4.66 & 0.10 \\ 28.8 & 15.9 & \mathbf{6 . 3 8} & \mathbf{0 . 0 4} & 25.4 & 17.2 & 2.84 & 0.24\end{array}$
mother-in-law and siblings) in family planning decisions is important in the consolidation of extended family and social relations

3 I am in favor of early marriage to the girl before the age of 18 years

$4 \quad$ Early marriage helps to have more children

Female students had significantly more positive attitudes than male students in posttest

5 The presence of a male child in the family is something essential

6 Having a child during the first year of marriage strengthens the marital relationship and supports its stability

No significant difference between genders in pretest and posttest

7 If a couple decided to have a certain number of children, it is worth not to do birth spacing

8 It is necessary to introduce reproductive health to a school curriculum that fits school children ages

9 The benefits of family planning not only are reflected on individuals and families but also extend to communities

10 The decision about birth spacing and selecting family planning method is a shared decision between the couple

II Women need the social support of her partner in matters related to family planning

12 A man has to accompany his wife for consultation related to family planning

13 Family planning methods should be tried by women first, and if it does not work, methods for men could be used

14 Marriage is predestined and fated and is not a choice

15 The main purpose of marriage is procreation and reproduction only

16 Early marriage (before 18 years of age) is one of the important factors that lead to instability of marriage thus the occurrence of divorce

17 Discussing intimacy issues by young women and men with their parents is unacceptable before marriage

18 If one or both of the fiancés discovered that they carry the gene for thalassemia, they should not marry

19 Contracting sexually transmitted infections is divine punishment that affects bad people

20 It is better not to raise the subject of premarital physical examination related to sexually transmitted diseases

21 If someone discovered that he has a sexually transmitted disease, the patient should forever be separated from her/his partner

$\begin{array}{llllllll}52.5 & 36.4 & 4.96 & 0.006 & 0 & 2 & 1.65 & 0.44 \\ 33.9 & 29.1 & 12.46 & 0.002 & 30.5 & 23.8 & 1 & 0.61 \\ 55.9 & 37.7 & 6.15 & 0.05 & 39 & 23.8 & 6.47 & 0.04 \\ 57.6 & 48.3 & 5.13 & 0.08 & 55.9 & 42.4 & 6.69 & 0.04\end{array}$

$22 \quad 126$

89.8

(2.7

5.17

0.08

22

15.2

1.68

0.43

$93.2 \quad 96$

96.696 .7

0.46

0.80

96.6

91.4

2.07

0.36

96

1.48

0.48

94.9

94.7

I.52 0.47

$96.6 \quad 96.7$

2.12

0.35

98.3

96.7

$0.8 I \quad 0.67$

$94.9 \quad 97.4$

3.33

0.19

100

97.4

1.59

0.45

$94.9 \quad 96$

5.78

0.06

98.3

95.4

2.03

0.36

$61 \quad 64.9$

0.37

0.83

54.2

$\begin{array}{ll}52.5 & 36.4\end{array}$

4.96

0.08

40.7

54.3

0.17

0.92

$\begin{array}{ll}6.8 & 6.6\end{array}$

0.13

0.94

I.7

25.8

4.61

0.10

$15.3 \quad 10.6$

$\begin{array}{ll}3.32 & 0.19\end{array}$

81.4

76.8

2.75

0.25

23.

28.5

1.66

0.44

11.9

25.8

5.72

0.06

$\begin{array}{ll}57.6 & 72.8\end{array}$

$\begin{array}{ll}5.08 & 0.08\end{array}$

61

67.5

3.56

0.17

$22 \quad 29.1$

I.19 0.55

22

27.8

2.48

0.29

$11.9 \quad 9.3$

0.77

0.68

11.94

4.62

0.10

63.6

$\begin{array}{ll}5.14 & 0.08\end{array}$

Note: Bold represents $p<0.05$, which is a significant result. 
more independence, thus having extra responsibilities due to early marriage and a large number of children would hinder women's progress.

Our study gives the hope to bridge the gap between the genders as it revealed that significant increment in knowledge and attitude of the university students was evident after interactive teaching regardless of their gender sessions. It was evident that when education is offered for both genders and engaging males in such style of teaching, the difference in knowledge scores between genders was minimal. Findings from this study revealed the usefulness of the interactive teaching approach to achieve the course goals that are consistent with Ulubey and Gözütok study. ${ }^{17}$ To further support our findings, larger intervention studies at the national level are recommended.

Based on Hindin and Fatusi's review, ${ }^{18}$ in developing countries, parents are among the preferred sources of information about sex and RH among adolescents. Based on the current study's results, which indicated an improvement in students' knowledge and attitudes toward RH, youths have another source of knowledge in addition to their parents.

In the current study, the majority of the participants supported the introduction of topics about RH to school curriculum that are appropriate for school children level of development and socially acceptable. Therefore, the collaboration between the Ministry of Health and the Ministry of Education to introduce RH to school children at an early age would lay solid foundations for future $\mathrm{RH}$ and help to break barriers in discussing these issues.

Health education in the university environment is a costeffective and ideal method of developing healthy lifestyles among university students who are in a distinctive phase of gaining knowledge and shaping personality. ${ }^{13}$ This can be done by integrating concepts of $\mathrm{RH}$ into curricular and extracurricular activities of university education and effectively using interactive teaching approaches. These promising initiatives would build a partnership between young people and adults via participation in educational programs and increase the access to valid information and services on $\mathrm{RH}$.

Despite the significant improvement in students' knowledge and attitudes toward RH, still there were some aspects that did not improve as expected. For example, in our study, after the intervention, more than half of the students still believed that women should use family planning methods first. Our speculation for these results is that RH may be particularly important for females because they give births and are responsible for child-rearing. Although the Jordanian culture keeps men out of the picture when it comes to $\mathrm{RH}$ and considers that RH is relevant only to women, men have the final decision on major issues related to procreation such as number of children a family should have. ${ }^{6}$

In our study, the majority of the students extended from families with an average size of 6-7 family members with one third of them extending from families with an average of 8-10 family members. This finding reflects the steady rise in fertility rates (3.4) in Jordan. ${ }^{19}$ Particularly, family size increased in low-income families; the average family size for low-income families is $7.2{ }^{1}$ These results further indicate the need to educate youths about $\mathrm{RH}$ issues.

Given that in Arab and Muslim society culture, social norms and religion regulate marriage and sexuality, ${ }^{20}$ this might explain the results of some items such as women's and men's roles in RH and decision making. The study results showed that even after the study intervention, around half of the students did not know that birth control pills are among the most effective means of family planning, although this piece of knowledge is critically important among those who were close to getting married. Given that our study sample is composed of university students, on the one hand, almost all students in our sample were single, and on the other hand, obtaining information relevant to family planning is socially acceptable only after marriage. ${ }^{20}$ For these reasons, we contemplate that students did not pay a lot of attention to family planning during the course as this information has no use for them for the time being. A similar finding was identified for premarital screening tests in Jordan, as around quarter of the students still did not know whether STIs are included in the premarital tests in Jordan even after the intervention. It could be explained that some of the students do not even think about STI tests before marriage because premarital sex is forbidden and both the couple must be virgin. ${ }^{21}$ Due to the strong value of abstinence before marriage which is an outgrowth of Islamic doctrine, it may explain why around quarter of the students believe that STI is a divine punishment and around half of the students believe that if someone discovered that his spouse has STI should permanently be separated from him.

Other results sound expected in our culture such as believing that having children in particular a male child is important for the family stability and continuity. Even after the study intervention, male students reported less opposition on the importance of having a male child and having children soon after marriage. This may be in part due to cultural factors $^{22}$ and marital adversities that may affect women without children. ${ }^{23}$ During the past decades, the Jordanian society was male dominant, thus men had more 
privileges; however, nowadays women are more educated and economically productive. These privileges enable women to be independent and equally involved in decision making as men. These issues need to be emphasized when educating youth regarding $\mathrm{RH}$ issues.

To our knowledge, the current study is the first one that employed interactive teaching approach to raising the awareness about RH issues among both male and female university students in Jordan and the Arab region. Our study is different because, first, it sheds light on gaps in RH knowledge that were identified by university students and provides an effective approach to fill these gaps. We also interpreted the results in the context of the Jordanian culture that is considered to be conservative where discussing $\mathrm{RH}$ issues is very sensitive. ${ }^{24}$ Our suggestion to improve youth's knowledge and attitudes toward RH and to bridge the gap between genders is by integrating RH education in schools and universities.

\section{Limitations}

Considering the limitation of our self-report pilot study using a convenience sample, the findings might be enhanced by a large-scale randomized control study at a national level. Students' self-selected method may have biased the sample, by having students who were more concerned about RH; hence, random sampling would decrease the potential bias in future studies. Our study sample was composed of welleducated youth who mainly reside in the north of Jordan; it would be informative if other studies conducted among youth who are not enrolled in universities at the national level. The study measure was newly developed due to unavailability of culturally suitable scale; it might not have captured all the important aspects of RH knowledge and attitudes which warrant refinements. Also, using self-report questionnaire may invite socially desirable answers. The cross-sectional design prevents causality inference. Finally, conducting qualitative studies to explore experiences from students might also be useful.

\section{Conclusion}

Our pilot study provided preliminary indications of the usefulness of the introduction of RH topics by using interactive teaching methods in promoting $\mathrm{RH}$ among university students. However, these results should be strengthened before adopting this initiative at universities and schools in a conservative culture as Jordan.

\section{Acknowledgments}

The authors would like to thank the UNFPA and Royal Health Awareness Society (RHAS) in Jordan for the intensive training workshops provided to the researchers to effectively use the interactive learning methods in conducting health promotion course, without which the study could not have come to a successful conclusion. The study received funding from the RHAS in Jordan (Fund no. RHAS/16/OM/272) through the partnership with UNFPA. We would also like to acknowledge the academic support we received from Deanship of Academic Research at The Jordan University of Science and Technology.

\section{Disclosure}

The authors report no conflicts of interest in this work.

\section{References}

1. Department of Statistics. Jordanian Population and Family Health Survey; 2012. Available from: https://dhsprogram.com/pubs/pdf/fr282/ fr282.pdf. Accessed December, 1, 2017.

2. Khalaf I, Moghli FA, Froelicher ES. Youth-friendly reproductive health services in Jordan from the perspective of the youth: a descriptive qualitative study. Scand J Caring Sci. 2010;24(2):321-331.

3. USAID. Gender Analysis and Assessment; 2012. Available from: http://haqqi.info/en/haqqi/research/usaidjordan-gender-analysis-andassessment. Accessed December 1, 2017.

4. Hijazi HH. Factors Affecting Contraceptive Use Among Women of Reproductive Age in Northern Jordan: A Framework for Health Policy Action [dissertation]; 2012. Available from: http://ir.library.oregonstate. edu/concern/graduate_thesis_or_dissertations/12579w423. Accessed December 2, 2017.

5. Kradsheh M. Female early marriage: its determinants and effects on demographic behavior in Jordan. Jordan J Soc Sci. 2012;5(1):37-59.

6. Higher Population Council and Health Policy Project. Jordan National Reproductive Health/Family Planning Strategy at a Glance; 2013. Available from: https://www.healthpolicyproject.com/pubs/239_JordanNationalRHStrategyBrief.pdf. Accessed November 1, 2017.

7. DeJong J, Jawad R, Mortagy I, Shepard B. The sexual and reproductive health of young people in the Arab countries and Iran. Reprod Health Matters. 2005;13(25):49-59.

8. USAID. Knowledge, Attitudes, and Practices Toward Family Planning and Reproductive Health Among Married Women of Reproductive Age in Selected Districts in Jordan; 2015. Available from: https://jordankmportal. $\mathrm{com} /$ resources/knowledge-attitudes-and-practices-toward-family-planning-and-reproductive-health-among-married-women-of-reproductiveage-in-selected-districts-in-jordan. Accessed July 1, 2017.

9. Mahadeen A, Khalil A, Hamdan-Mansour A, Sato T, Imoto A. Knowledge, attitudes and practices towards family planning among women in the rural southern region of Jordan/Connaissances, attitudes et pratiques des femmes en matiere de planification familiale dans le sud rural de la Jordanie. East Mediterr Health J. 2012;18(6):567.

10. Johns Hopkins University, Centre for Communication Programs, National Population Commission, Jordan. Jordanian Youth Survey: Knowledge, Attitudes and Practice on Reproductive Health and Life Planning. Amman: Johns Hopkins University; 2001.

11. UNICEF. Jordan Population and Housing Census 2015; 2015. Available from: https://www.unicef.org/jordan/resources_10112.html. Accessed July 15, 2017.

12. WHO. Trends in Maternal Mortality: 1990-2015: Estimates from WHO, UNICEF, UNFPA, World Bank Group and the United Nations Population Division; 2015. Available from: http://www.who.int/gho/ maternal_health/countries/en/. Accessed July 15, 2017.

13. Wang D, Xing X-H, Wu X-B. Healthy lifestyles of university students in China and influential factors. ScientificWorldJournal. 2013;2013:412950. 
14. Abu-Moghli FA, Khalaf IA, Barghoti FF. The influence of a health education programme on healthy lifestyles and practices among university students. Int J Nurs Pract. 2010;16(1):35-42.

15. Haberland NA. The case for addressing gender and power in sexuality and HIV education: a comprehensive review of evaluation studies. Int Perspect Sex Reprod Health. 2015;41(1):31-42.

16. Schoemaker J, Yassa A, Farah S, Qardan L, Jaroudi L, El-Sarayrah M. Jordanian Youth Survey: knowledge attitudes and practices on reproductive health and life planning. Final Report; 2001. Available from: http:// www.share-net-jordan.org.jo/?q=en/node/11883. Accessed December 4, 2017.

17. Ulubey Ö, Gözütok FD. Future citizenship, democracy and human rights education with creative drama and other interactive teaching methods. Egitim ve Bilim. 2015;40(182):87-109.

18. Hindin MJ, Fatusi AO. Adolescent sexual and reproductive health in developing countries: an overview of trends and interventions. Int Perspect Sex Reprod Health. 2009;35(2):58-62.
19. The World Bank. Fertility Rate, Total (Births per Woman); 2014. Available from: https://data.worldbank.org/indicator/SP.DYN.TFRT.IN/. Accessed December 1, 2017.

20. Musso S, Fanget D, Cherabi K. An Arab-Muslim view. Prospect. 2002;32:207-215.

21. Smerecnik C, Schaalma H, Gerjo K, Meijer S, Poelman J. An exploratory study of Muslim adolescents' views on sexuality: implications for sex education and prevention. BMC Public Health. 2010;10(1):533.

22. Al-Akour N. Relationship between parental knowledge of fetal gender and newborns' birthweight among Jordanian families. Int J Nurs Pract. 2009; 15(2):105-111.

23. Obeisat S, Gharaibeh MK, Oweis A, Gharaibeh H. Adversities of being infertile: the experience of Jordanian women. Fertility Sterility. 2012;98(2):444-449.

24. Tabatabaie A. Childhood and adolescent sexuality, Islam, and problematics of sex education: a call for re-examination. Sex Educ. 2015;15(3):276-288.
Journal of Multidisciplinary Healthcare

\section{Publish your work in this journal}

The Journal of Multidisciplinary Healthcare is an international, peerreviewed open-access journal that aims to represent and publish research in healthcare areas delivered by practitioners of different disciplines. This includes studies and reviews conducted by multidisciplinary teams as well as research which evaluates the results or conduct of such teams or health

\section{Dovepress}

care processes in general. The journal covers a very wide range of areas and welcomes submissions from practitioners at all levels, from all over the world. The manuscript management system is completely online and includes a very quick and fair peer-review system. Visit http://www.dovepress.com/ testimonials.php to read real quotes from published authors. 